\title{
Home Variables as Predictor of Students' Achievements in Social Studies in Junior Secondary Schools in Osun State, Nigeria
}

\author{
Babatunde Adeniyi Adeyemi ${ }^{1}$ \\ ${ }^{1}$ Institute of Education, Faculty of Education, Obafemi Awolowo University, Ile-Ife, Nigeria \\ Correspondence: Babatunde Adeniyi Adeyemi, Institute of Education, Faculty of Education, Obafemi Awolowo \\ University, Ile-Ife, Nigeria. E-mail: adeyemibabs2003@yahoo.com
}

Received: June 25, 2015 Accepted: January 14, 2016 Online Published: February 23, 2016

doi:10.5539/ass.v12n3p222

URL: http://dx.doi.org/10.5539/ass.v12n3p222

\begin{abstract}
The study investigated the relationship between home variables and students' achievement in Social Studies. This is with a view of enhancing students' better performance in Social Studies. The study employed the survey research design. The population consisted of the Junior Secondary School Students in Osun State. Stratified sampling technique was employed in selecting 500 students in five purposively selected local governments in Osun State. Two instruments titled "Home Variables Questionnaire" (HVQ) and "Social Studies Achievement Test" (SSAT) were constructed by the researcher to elicit information from the subjects. The two instruments yielded 0.71 and 0.84 respectively using Cronbach alpha. Seven out of the nine variables were found to be significant predictors of students' achievement in Social Studies; $(\operatorname{Sex} \beta=1.98 ; \mathrm{t}=4.93 ; \mathrm{p}<0.05$, age $\beta=-1.16$, $\mathrm{t}=-3.42 ; \mathrm{p}<0.05$, ethnic group $\beta=0.51 ; \mathrm{t}=-6.95 ; \mathrm{p}<0.05$, religion $\beta=-2.86, \mathrm{t}=-6.95 ;<0.05$ parent living pattern $\beta=-2.66 ; \mathrm{t}=-2.92 \mathrm{p}<0.05$, number of fathers' wives $\beta=5.25 ; \mathrm{t}=4.21 ; \mathrm{p}<0.05$, mother's position among wives $\beta=-3.39 ; \mathrm{t}=-4.718 ; \mathrm{p}<0.05)$ whereas the two other variables were not predictors of students' achievement (mother's no of children $\beta=0.19 ; \mathrm{t}=1.78 ; \mathrm{p}>0.05$, and position in the family $\beta=0.01, \mathrm{t}=0.010, \mathrm{p}>0.05$ ). Also, there was significant difference in male and female students' achievement in Social Studies $(t=9.991, p<0.05)$. Furthermore, there was a significant relationship between home facilities and students' achievement in Social Students $(\mathrm{r}=0.180 ; \mathrm{p}<0.05)$ whereas there was no significant relationship between birth order and students' achievement $(\mathrm{r}=0.050, \mathrm{p}>0.05)$. The study recommended among others that government should provide schools with adequate infrastructures and facilities that will enhance effective learning environment.
\end{abstract}

Keywords: home variables, achievement in social studies, JSS students

\section{Introduction}

Education is an inevitable need of life. It has been defined by various experts and educationists. Education according to Oladosu (2004) means a set of activities which entail handing down the ideas, values and norms of the society across generations. It involves the transmission of knowledge, skills, attitudes and beliefs. These ideas are properly learnt through Social Studies as a discipline. According to Adeyemi (2014) Social Studies deals with people's interactions with their environments which involve reciprocal relationships to tackle societal challenges. Fafunwa (1981) sees education as the transfer of knowledge, social skills, values, attributes from one generation to another through the society in which an individual was born. All societies have arrangements for taking care of their young children. These arrangements, through socialization processes, have evolved overtime and are diverse across cultures, in keeping with differences in family and community structures and the social and economic roles of men and women (Blumberg, 2006; UNESCO GNU, 2007). However, current social and economic trends are disrupting many existing child care arrangements especially in Nigerian households where child rearing and career development is not only the responsibility of the parents but of everybody in the extended household (Albert, Awe, Herault, \& Omitoogun, 1995).

Children are fundamental to the society because they are our future; they hold the key to change and in turn a successful future in their hands (Gratz, 2006). Therefore, the society's duty is to provide them with a complete education that teaches them how to work together, how to question what is in front of them and how to be catalyst of change. Education starts with what children learn from their parents and from what they learn in the first few years of their lives. This initial education impacts the rest of their lives and inherently society's future.

By its design, Social Studies should enable people to tackle societal challenges by helping environment adapt to 
the ever-changing environment they live in through the acquisition of relevant knowledge attitudes, values and practical skills. Thus Social Studies was designed to provide functional and social education to Nigerian children and youths who are rich in the knowledge of Social Studies concepts and facts but deficient in expected values, attitude and behaviour that characterize socially responsible citizens. No wonder the use of Social Studies is germane to this study.

Investigations that have adopted refined measures of family influences have tended to show that they are related more strongly to academic outcomes than are more global measures of family background. Kellaghan (1993) concludes, for example, that family social status or cultural background need not determine a child's achievement at school. He proposes that for academic success, it is what parents do in the home, and not children's family background, that is significant. Similarly, Redding (1999) indicates that in relation to academic outcomes, the potential limitations associated with poor economic circumstances can be overcome by parents who provide stimulating, supportive, and language-rich experiences for their children. In another development Fitchet (2010) had observed that students tend to perform better when there are appropriate and conducive arrangements for their transportation to and from their respective schools.

It is also important to note that home variables such as family background, socio-economic status are capable of influencing students' performance in any subject. Stephen (1997) proposes that the efficacy of a family influence for academic success is determined to a large degree by a child's family background. He observed that parent-child interactions are the forces that lead to academic performance. In addition, he equally claim that academic success is achieved only if family background resources can be accessed to maximize the association between family influences and outcomes: relationships between family influences and academic achievement need to take into account the potentially constraining or expanding opportunities provided by children's family backgrounds.

\section{Statement of the Problem}

There has been a long standing fascination with exploring associations between home variables and students' academic performance. Researchers in the past have dealt extensively on issues related to home variables and students' academic performance. However, there is dearth in literature most essentially in Nigeria in some aspects of home variables such as position in the family, sex, mother's position among wives, ethnic groups, mother's number of children, age, parent living pattern, religion and number of father's wives. It is therefore essential to examine these variables in the light of students' academic performance in Social Studies; hence this study.

\section{Hypotheses}

1. There is no significant relationship between students' home background and their achievement in Social Studies.

2. There is no significant sex difference in the academic achievement of students' in Social Studies.

3. Students birth order will not significantly influence their achievement in Social Studies.

4. There is no significant relationship between fathers' variables and students' achievement in Social Studies.

5. There is no significant relationship between mothers' variables and students' achievement in Social Studies.

6. There is no significant influence of home facilities on students' achievement in Social Studies.

\section{Methodology}

The study employed the survey research design. The population consisted of all the Junior Secondary School Students in Osun State. Stratified sampling technique was employed in selecting 500 students in five purposively selected local governments in Osun State. Two instruments titled "Home Variables Questionnaire" (HVQ) and "Social Studies Achievement Test" (SSAT) were constructed by the researcher to elicit information from the subjects. The two instruments were validated before use and the reliability coefficient yielded 0.71 and 0.84 respectively using Cronbach alpha. Six research hypotheses were tested. The data generated are analysed with the use of Pearson Correlation, Multiple Regression and t-test statistical analyses.

\section{Results}

1. There is no significant relationship between students' home background and their performance in Social Studies. 
Table 1. Regression coefficient of home variables on students' achievement in social studies

\begin{tabular}{cccccccc}
\hline \multirow{2}{*}{ Model } & \multicolumn{2}{c}{$\begin{array}{c}\text { Unstandardized } \\
\text { coefficients }\end{array}$} & $\begin{array}{c}\text { Standardized } \\
\text { Coefficients }\end{array}$ & $\mathrm{t}$ & Sig. & Remarks \\
\cline { 2 - 4 } & $\mathrm{B}$ & Std Error & Beta & & & \\
\hline Constant & 23.115 & 1.459 & & 15.840 & 0.000 & \\
Sex & 1.979 & 0.402 & 0.275 & 4.926 & 0.000 & $<0.05$ \\
Age & 1.159 & 0.339 & 0.202 & 3.414 & 0.001 & $<0.05$ \\
Ethnic group & 0.513 & 0.143 & 0.158 & 3.590 & 0.000 & $<0.05$ \\
Religion & .857 & 0.411 & 0.421 & 6.954 & 0.000 & $<0.05$ \\
Parent living pattern & 2.659 & 0.912 & 0.240 & 2.915 & 0.004 & $<0.05$ \\
No fathers' wives & 5.247 & 1.246 & 0.732 & 4.212 & 0.000 & $<0.05$ \\
Mother's position among wives & 3.390 & 0.719 & 0.702 & 4.716 & 0.000 & $<0.05$ \\
Mother's no of children & 0.187 & 0.105 & 0.091 & 1.779 & 0.076 & $>0.05$ \\
Position in the family & 0.010 & 0.095 & 0.005 & $0 ; 104$ & 0.917 & \\
\hline
\end{tabular}

Note: Predictors: (Constant) sex, age, ethnic group, religion, parent living pattern, no of father's wives, mother's position among wives; Dependent variables: Achievement in Social Studies; Significant; $(\mathrm{p}<0.05)$

Table 1 shows that seven out of the nine variables were found to be significant predictors of students' achievement in Social Studies ( $\operatorname{Sex} \beta=1.98 ; \mathrm{t}=4.93 ; \mathrm{p}<0.05$, age $\beta=-1.16 ; \mathrm{t}=-3.42 ; \mathrm{p}<0.05$. ethnic group $\beta=0.51$; $\mathrm{t}=-6.95 ; \mathrm{p}<0.05$, religion $\beta=-2.86, \mathrm{t}=-6.95 ;<0.05$ parent living pattern $\beta=-2.66 ; \mathrm{t}=-2.92 \mathrm{p}<0.05$, number of fathers' wives $\beta=5.25 ; \mathrm{t}=4.21 ; \mathrm{p}<0.05$, mother's position among wives $\beta=-3.39 ; \mathrm{t}=-4.718 ; \mathrm{p}<0.05$ ) whereas the two other variables are found not to be predictors of students' achievement (mother's no of children $\beta=0.19$; $\mathrm{t}=1.78 ; \mathrm{p}>0.05$, position in the family $\beta=0.01, \mathrm{t}=0.010, \mathrm{p}>0.05$ ).

2. There is no significant sex difference in the Academic Achievement of Students' in Social Studies.

Table 2. Sex difference in social studies achievement

\begin{tabular}{ccccccccc}
\hline Variable & Sex & $\mathrm{N}$ & $\mathrm{X}$ & $\mathrm{SD}$ & $\mathrm{df}$ & $\mathrm{t}$ & $\mathrm{P}$ & Remark \\
\hline \multirow{2}{*}{ Social Studies Achievement } & Male & 335 & 21.75 & 3.447 & \multirow{2}{*}{498} & \multirow{2}{*}{-9.991} & \multirow{2}{*}{0.000} & $<0.05$ \\
\cline { 2 - 7 } & Female & 165 & 24.69 & 2.213 & & & & \\
\hline
\end{tabular}

The results in Table 2, shows that there is significant difference in the achievement of male and female students in Social Studies. $(\mathrm{t}=9.991, \mathrm{p}<0.05)$

3. Students birth order will not significantly influence their achievement in Social Studies

Table 3. Relationship between birth order (position in the family) and achievement in Social Studies

\begin{tabular}{cccc}
\hline & & Position in the family & Achievement in Social Studies \\
\hline $\begin{array}{c}\text { Position in the } \\
\text { family }\end{array}$ & Person Correlation & 1 & 0.050 \\
& Sig. (2-tailed) & & 0.261 \\
Achievement & $\mathrm{N}$ & 500 & 500 \\
test & Pearson Correlation & 0.050 & 1 \\
& Sig. (2-tailed) & 0.261 & 500 \\
\hline
\end{tabular}

* Correlation is significant at the 0.05 level (2-tailed) 
The Pearson correlation analysis yields the value of 0.050 at 0.05 confidence level. This shows that there is no significant relationship between one's position in the family and students' achievement in Social Studies. $(\mathrm{r}=0.050, \mathrm{p}>0.05)$

4. There is no significant relationship between fathers' variables and students' achievement in Social Studies

Table 4.

\begin{tabular}{cccccccc}
\hline \multirow{2}{*}{ Model } & \multicolumn{2}{c}{$\begin{array}{c}\text { Unstandardized } \\
\text { coefficients }\end{array}$} & $\begin{array}{c}\text { Standardized } \\
\text { Coefficients }\end{array}$ & $\mathrm{t}$ & Sig. & Remarks \\
\cline { 2 - 5 } & $\mathrm{B}$ & Std Error & Beta & & & \\
\hline Constant & 0330 & 1.930 & & 0.171 & 0.864 & \\
Father's age & 2.157 & 0.267 & 0.426 & 8.077 & 0.000 & $<0.05$ \\
Father's ethnic group & 0.096 & 0.161 & 0.029 & 0.595 & 0.552 & $>0.05$ \\
Father's religion & 0.643 & 0.353 & 0.095 & 1.820 & 0.069 & $>0.05$ \\
Father's highest level of education & 0.472 & 0.092 & 0.203 & 5.117 & 0.000 & $<0.05$ \\
Father's occupation & 1.294 & 0.204 & 0.305 & 6.343 & 0.000 & $<0.05$ \\
Father's marital status & 0.769 & 0.161 & 0.227 & 4.766 & 0.00 & $<0.05$ \\
Father's no of children & 0.515 & 0.147 & 0.204 & 3.513 & 0.000 & $<0.05$ \\
\hline
\end{tabular}

Note: Predictors (constant) father's age, father's highest level of education, father's occupation, father's marital status and father's number of children: Dependent variable: Achievement in Social Studies: Significant $(\mathrm{p}<0.05)$

Table 4 shows that five out of the seven variables were found to be significant predictors of students' achievement in Social Studies. (father's age $\beta=2.16$; $\mathrm{t}=8.08$; $\mathrm{p}<0.05$, father's highest level of education $\beta=0.47$; $\mathrm{t}=5.12 ; \mathrm{p}<0.05$, father's occupation $\beta=1.29 ; \mathrm{t}=-6.34 ; \mathrm{p}<0.05$, father's marital status $\beta=0.77, \mathrm{t}=4.75 ;<0.05$ father's number of children $\beta=0.52 ; \mathrm{t}=3.51 \mathrm{p}<0.05$ ) whereas the two other variables are found not to be predictors of students' achievement (fathers ethnic group $\beta=0.096 ; \mathrm{t}=0.595 ; \mathrm{p}>0.05$, fathers religion $\beta=0.64$, $\mathrm{t}=1.82, \mathrm{p}>0.05$ )

5. There is no significant relationship between mother's variables and students' achievement in Social Studies

Table 5 .

\begin{tabular}{cccccccc}
\hline \multirow{2}{*}{ Model } & \multicolumn{2}{c}{$\begin{array}{c}\text { Unstandardized } \\
\text { coefficients }\end{array}$} & $\begin{array}{c}\text { Standardized } \\
\text { Coefficients }\end{array}$ & $\mathrm{t}$ & Sig. & Remarks \\
\cline { 2 - 5 } & $\mathrm{B}$ & Std Error & Beta & & & \\
\hline (Constant) & 23.246 & 1.039 & & 22.374 & 0.000 & \\
Mother's age & 0.936 & 0.120 & 0.356 & 7.781 & 0.000 & $<0.05$ \\
Mother's ethnic group & -0.382 & 0.208 & -0.083 & -1.837 & 0.067 & $>0.05$ \\
Mother's religion & -1.308 & 0.394 & -0.178 & -3.318 & 0.001 & $<0.05$ \\
Mother's highest level of education & 0.003 & 0.149 & 0.001 & 0.023 & 0.982 & $>0.05$ \\
Mother's occupation & 0.482 & 0.244 & 0.120 & 1.976 & 0.049 & $<0.05$ \\
Mother's marital status & -0.326 & 0.165 & -0.091 & -1.978 & 0.048 & $<0.05$ \\
Mother's no of children & -0.201 & 0.147 & -0.073 & -1.373 & 0.170 & $>0.05$ \\
\hline
\end{tabular}

Note: Predictors (constant) mother's age, mother's religion, mother's occupation and mother's marital status: Dependent variable: Achievement in Social Studies: Significant $(\mathrm{p}<0.05)$

Table 5 shows that four out of the seven variables were found to be significant predictors of students' achievement in Social Studies. (mother's age $\beta=0.94 ; \mathrm{t}=7.78 ; \mathrm{p}<0.05$, mother's religion $\beta=-1.31 ; \mathrm{t}=-3.32 ; \mathrm{p}<0.05$, 
mother's occupation $\beta=0.48 ; \mathrm{t}=-1.98 ; \mathrm{p}<0.05$, mother's marital status $\beta=-0.33, \mathrm{t}=-1.99 ;<0.05)$ whereas the three other variables are found not to be predictors of students' achievement (mother's ethnic group $\beta=-0.38 ; \mathrm{t}=-1.84$; $p>0.05$, mothers highest level of education $\beta=0.003, t=0.023, p>0.05$; mother's number of children $\beta=-0.20$, $\mathrm{t}=-1.37 ; \mathrm{p}>0.05)$.

6. There is no significant influence of home facilities on students' Achievement in Social Studies

Table 6. Relationship between home facilities (home gadget) and achievement in Social Studies

\begin{tabular}{cccc}
\hline & & Parents home gadget & Achievement in Social Studies \\
\hline \multirow{3}{*}{ Parent home gadget } & Person Correlation & 1 & $0.180^{* *}$ \\
& Sig. (2-tailed). & & 0.000 \\
& $\mathrm{~N}$ & 500 & 500 \\
\hline \multirow{3}{*}{ Achievement test } & Pearson Correlation & $0.180^{* *}$ & 1 \\
& Sig. (2-tailed) & 0.000 & 500 \\
\hline
\end{tabular}

${ }^{*}$ Correlation is significant at the 0.05 level (2-tailed)

The Pearson correlation analysis yields significant value of 0.180 at 0.05 . This shows that there is a significant relationship between home facilities and students' achievement in Social Studies. $(r=0.180 ; p<0.05)$.

\section{Discussion}

Based on the findings of this study, seven variables (sex, age, ethnic group, religion, parent living pattern, no of father's wives, mother's position among wives) were found to be predictors of students' achievement in Social Studies. Also, the results equally revealed that there is significant difference in achievement of males and female students' in Social Studies. The results tallied with Lewine (2011); Zembair \& Blume (2011) and Chalachew \& Lakshmi (2013) who were of the views that sex played a significant role in academics performance of students.

There is also a significant relationship between facilities and students' achievement in Social Studies, whereas, there is no significant relationship between birth order and students' achievement in Social Studies. This study is in line with previous research studies. Morgan, Farkas, Hilemeier, and Maczuga, (2009) observed that children from low socio-economic status and communities develop academic skills more slowly compared to children from higher SES groups. And also the findings of Onabamiro, Ositoye \& Adeyemi (2010); Hussain \& Khan (2012) whose their results showed that male were significantly better than female at different level of birth order and that student birth order often affects personality, self esteem and cognitive achievements.

Also, according to Orr (2003) parents from low socio-economic community may be unable to afford resources such as books, computers or tutor to create positive literacy environments. Not only that, Coley, (2002) observed that the nationwide study of American kindergarten children, $36 \%$ of parents in the lowest income quintile read to their children on a daily basis, compared with $62 \%$ of parents from the highest income quintile. National Centre for Education Statistics (2008) observed that in 2007, the high school dropout rate among persons 16 - 24 years old was highest in low-income families (16.7\%) as compared to high income families $(3.2 \%)$. This study also tallied with Flouri \& Buchanan (2010); Alokan Osakinle \& Onijingin (2013); Fareo \& Ojo (2013) and Egunsola (2014) who were of the views that parental status, family sizes and study facilities could not be divorced in the attainment of student academic performance.

\section{Conclusion}

There is no doubt home variables play a very significant role in academic achievement of students in Social Studies which has been found to be negatively affecting the performance of students. This is likely due to lack of proper preparation and training on the part of the parent before having children. Children in turn will not be able to get all the essential facilities that could enhance their academic achievement.

\section{Recommendations}

1. There should be a regulation from government on the number of wives a man should have. This is likely to reduce parents' inability to cater for the educational development of their wards.

2. Parents should as much as possible provide stimulating, supportive and language-rich experience for their 
children.

3. Government should provide schools with adequate infrastructures and facilities that will enhance effective learning environment.

4. Ethnic bias and religious affiliations should be guided against in the educational attainment of the students.

\section{References}

Adeyemi, B. A. (2014). Self concept and motivation variables as correlates of acquisition of ICT competence among Social Studies students of Obafemi Awolowo University, Ile-Ife, Nigeria. World Journal of Education, 4(2), 76-87. http://dx.doi.org/10.5430/wje.v4n2p76

Albert, I., Awe, T., Herault, G., \& Omotogun, W. (1995). Informal channels for conflict resolution in Ibadan, Nigeria. Ibadan: Institute Fracais de recherhe en Afrique

Alokan, F. B., Osakinle, E. O., \& Omijingin, E. O. (2013). The influence of parents' educational background and study facilities on academic performance among secondary school students in Ondo State. Ozean Journal of Social Sciences, 6(2), 27-33.

Blumberg, R. L. (2006). How mother's economic activities and empowerment affect early childhood care and education for boys and girls. Paris: UNESCO.

Chalachew, A. A., \& Lakshmi, V. H. (2013). Assessing children academic achievement as correlative with Parents marital status: The case of junior high school students in Addis Ababa. International Journal of Social Sciences and Interdisciplinary Research, 2(2), 125-138.

Coley, P. D. (2002). Helping under achieving boys read well and often. Eric Digest. Retrieved from http://www.eric.digests.org/2002/boys/htm

Egunsola, A. O. E. (2014). Influence of family type and size on academic performance of secondary school students in Agricultural Science in Adamawa State, Nigeria. Journal of Humanities and Social Science, 19(11), 63-68. http://dx.doi.org/10.9790/0837-191146368

Fafunwa, A. B. (1981). New perspectives in African education. Lagos: Macmillan and Company Ltd.

Fareo, D. O., \& Ojo, O. O. (2013). Impact of facilities on academic performance of students with special needs in mainstreamed public schools in Southern Nigeria. Journal of Research in Special Educational Needs, 13920, 159-167.

Fitchett, P. G. (2010). A profile of twenty-first century secondary social studies teachers. Journal of Social Studies Research, 34(2), 229.

Flouri, E. S., \& Buchanan, A. (2010). Early father's and mother's involvement and child's later educational outcomes. British Journal of Educational Psychology, 74(2), 141-153. http://dx.doi.org/10.1348/00070990 4773839806

Gratz, J. (2006). The impact of parents' background on their children's education. Retrieved from http://www.macalester.edu/educationreform/publicatoinintellectualessay/grat2.df

Hussain, L. S., \& khan, U. A. (2012). Impact of birth order on academic achievement. Journal of Educational Research, 15(2), 27.

Kellaghan, T. (1993). The home environment and school learning: Promoting parental involvement in the education of children (pp. 155-180). USA: Jossey-Bass.

Lewine, R. (2011). Sex affect and academic performance: It's not what you think. International Journal for Scholarship of Teaching and Learning, 5(2). Retrieved from http://digitalcommons.geogiasouthern.edu/ijscot/vol15/Iss2/7

Morgan, P. L., Farkas, G., Hillemeier, M., \& Maczuga. (2010). Risk factors for learning related behaviour problems. Retrieved from http://www.ed.psu.edu/../paulmorgan

National Centre for Education. (2008). Ethnic and race as minorities and socio-economic status. Retrieved from http://www.apa.org/i/factsheet.com.aspx

Oladosu, A. G. A. S. (2004). Concept in education related to teaching in I. O. Abimbola and A. O. Abolade, Fundamental principles and practice of instruction. Ilorin: Department of Curriculum Studies and Educational Technology, University of Ilorin.

Onabamiro, A. A., Ositoye, A. O., \& Adeyemi, M. (2010). Influence and relationship of birth order and 
secondary school students' academic achievement. Academic Leadership, 8(4), 56.

Orr, A. J. (2003). Black-white differences in achievement: the importance of wealth. Sociology of Education, 76, 281-304. http://dx.doi.org/10.2307/1519867

Reading, S. (1999). Academic achievement family background and family structure. Retrieved from http://www.familyfrank/org/pages/11/academic.achievementfamilybackground.familystructure.html

Stephen, J. C. (1997). Family background and family structure. Retrieved from http://www.encyclopeadia.com/ doc/IG2.340690

UNESCO. (2007). Background paper for 2007 UNESCO Education for all global monitoring report. Strong foundations: Early childhood care and education (Electronic version 2007/ED/EFA/MRT/P/6).

Zembair, M. J., \& Blume, L. B. (2011). Gender and academic achievement. Pearson Allyn Bacon Prentice Hall. Retrieved from http://www.education.com/reference/article/gender-academic-achievement/

\section{Copyrights}

Copyright for this article is retained by the author(s), with first publication rights granted to the journal.

This is an open-access article distributed under the terms and conditions of the Creative Commons Attribution license (http://creativecommons.org/licenses/by/3.0/). 